\title{
Clinical presentation and markers of cutaneous versus systemic mastocytosis: the mastocytosis center at brigham and women's hospital in Boston
}

\author{
Kelly Yoshimi Kanamori ${ }^{1 *}$, Pedro Giavina-Bianchi ${ }^{1}$, Nathalia Pessoa Simis ${ }^{1}$, Cem Akin ${ }^{2,3}$, Mariana Castells ${ }^{2,3}$
}

From 3rd WAO International Scientific Conference (WISC) 2014

Rio de Janeiro, Brazil. 6-9 December 2014

\section{Background}

Mastocytosis is a group of heterogeneous diseases characterized by an abnormal expansion and accumulation of mast cells (MCs) in different tissues. While systemic mastocytosis (SM) is defined by the accumulation of MCs in bone marrow (BM) and different tissues, cutaneous mastocytosis $(\mathrm{CM})$ is characterized as an accumulation of $\mathrm{MC}$ in the skin with no other organ involvement. How gender differences, tryptase levels and episodes of anaphylaxis affect cutaneous versus systemic mastocytosis is not well understood.

\section{Methods}

We report a case series of 109 patients with SM and 59 with CM from the Mastocytosis Center at Brigham and Women's Hospital in Boston. The diagnosis of SM and $\mathrm{CM}$ were done according to the International Classification of Mastocytosis from WHO. We reviewed gender, tryptase levels and episodes of anaphylaxis in both populations.

\section{Results}

There was a female predominance which was more pronounced in SM $(68,8 \%)$ than in CM $(52,7 \%)$. The mean serum tryptase level was $11.5 \mathrm{ng} / \mathrm{ml}$ in $\mathrm{CM}$, and $14.9 \%$ of CM patients had serum tryptase levels above $20 \mathrm{ng} / \mathrm{ml}$. In SM patients the mean serum tryptase level was $97.2 \mathrm{ng} / \mathrm{ml}$ and $84 \%$ of the patients presented levels above $20 \mathrm{ng} / \mathrm{ml}$. The symptoms of CM included pruritus, flushing, urticaria, and dermatographism and $10.8 \%$ of the patients (number) had episodes of anaphylaxis. The rate of anaphylaxis in SM patients was found to be $29.4 \%$ similar to the previously reported.

\section{Conclusions}

A female predominance was seen in both cutaneous and systemic mastocytosis in contrast to other studies indicating that there is no gender predominance. Elevations of serum tryptase above $20 \mathrm{ng} / \mathrm{ml}$ and anaphylaxis were seen in a small proportion of patients with cutaneous mastocytosis, raising the question of the potential progression to systemic mastocytosis and the need to closely monitor this subset of patients.

\section{Authors' details}

${ }^{1}$ University of São Paulo, Brazil. ${ }^{2}$ Harvard Medical School, USA. ${ }^{3}$ Brigham \& Womens Hospital, USA.

Published: 8 April 2015

doi:10.1186/1939-4551-8-S1-A141

Cite this article as: Kanamori et al:: Clinical presentation and markers of cutaneous versus systemic mastocytosis: the mastocytosis center at brigham and women's hospital in Boston. World Allergy Organization Journal 2015 8(Suppl 1):A141.

${ }^{1}$ University of São Paulo, Brazil

Full list of author information is available at the end of the article 